\title{
Possibilities of mass valuation in land use in Hungary
}

\author{
Béla Cehla $^{1}$ - Ferenc Buzás ${ }^{2}$ - Sándor Kiss ${ }^{1}$ - István Szúcs ${ }^{2}$ - László Posta ${ }^{2}$ \\ ${ }^{1}$ Biblio Markt Ltd., Hungary \\ ${ }^{2}$ University of Debrecen Institute of Applied Economics Sciences, Hungary \\ buzas.ferenc@econ.unideb.hu
}

\begin{abstract}
SUMMARY
Technological development makes it possible to simplify and accelerate decision-making processes by adequately processing and evaluating large volumes of data. Sub-data obtained from large data sets have a very important practical role in asset valuation, forecasting and valuing delineated or difficult-to-map areas, or in the context of portfolio management. Land valuation is a separate segment within asset valuation and it requires a specific methodological approach on behalf of evaluators. In this study, the authors compared the transaction data of arable land and the value of other land use categories. Based on empirical assessments, the authors developed proposals for the fast and cost-effective determination of the value of land use categories other than arable land-mainly meadows and pastures.
\end{abstract}

Keywords: land valuation; land administration; mass valuation; valuation method; land use

\section{INTRODUCTION}

When an enterprise considers the use or extent of a given resource, e.g. land, it must first examine the expected demand and price conditions in the market of the products produced through the use of this resource, i.e. how the income-generating capacity of the given product will develop over time. The demand for production factors and resources, including arable land, basically considered is to be derived demand. In the authors' interpretation, derived demand means that a business is looking for a particular resource for the reason and to the extent that customers / consumers wish to buy the product / service produced with that resource, offering it at a price that provides them at least normal profit in the long run. Consequently, derived demand also means that the demand for production factors depends on the demand for the products produced with that given resource. Production factors, such as the land market, can never be a perfectly competitive market, as most of these resources are scarce. A company can obtain more of the scarcely available factors if it has a higher marginal productivity of a given factor and has the resources, information and networking capital needed to obtain them.

Accurate assessment of natural resources - i.e. considering them on a practical basis - is hampered by a number of methodological problems, such as assessment uncertainties affecting quality and productivity, methodological deficiencies in valuation, and internal inconsistencies in the price system when expressing the valuation in financial terms. The assessment is further complicated by the fact that natural resources are both the scene and the means of production. However, natural resources are not only a means of production, but also an asset, as it has a wealth-creating function, characterized by an increase in value well above continuous inflation. Arable land is an irreplaceable, objective expense, and it is a productive resource, which fundamentally affects the efficiency of farming, in addition to the fact that its productivity can be increased with reasonable interventions. The supply of soil is inflexible and its demand is mostly determined by the demand for the products produced on it, and the state transfers and subsidies related to its use. The structure of the estate, its location, the size of the field, the supply of nutrients, irrigation, the quality of the land, the golden crown (AK) value, clear and arranged ownership, the registered rights (e.g. pipeline rights-of-way), environmental classification (e.g. Natura 2000, Sensitive Natural Area, Less Favored Area, etc.) all have a significant impact on the current value of arable land.

Arable land, as a production factor, has a specific market. Due to the characteristics of land (e.g. fixed geographical location, the interconnection of production and biological processes, very different quality characteristics, slow capital turnover, etc.), the characteristics of a competitive market do not prevail in the land market. The land market is largely adapted to local supply and demand conditions and it is also specific in that arable land is fixed to a location and cannot be moved, therefore, its position is usually a function of changes in the environment. This is an important feature because, in many cases, land is often purchased for speculative purposes. The establishment of an industrial plant, the construction of a transport road, etc. can significantly change the position of lands, and thus their value. Eventually, land may be withdrawn from production or reclassified into a different land use category (e.g. inhabited land), the value of which may be many times the value of the original agricultural area.

Hungary's 4.3 million hectares of arable land account for $81 \%$ of the total agricultural area, while grasslands, including meadows and pastures, represent around $15 \%$ (HCSO, 2019). In Hungary, it can be observed that land ownership and land use are often separated from each other, often to a very significant extent. The efficient application of modern technologies is only possible with the proper farm size, which results in a process leading to a decrease in the number of farms but an increase in their average size 
(land concentration). However, in the land market, mobility is rather low. Owners strive to retain ownership of the land, i.e. divestment takes place only as a last option. The extent of the annual sale and purchase of land has been around $2-3 \%$ of the production area in the last decade, but it nearly doubled in recent years, due to the program called "Land for Farmers"1. Assessing the ex ante value of fragmented state-owned land required very significant physical and financial expenditures, while there was a need for valuation methods that allow for adequate value approximation, and low-cost valuation procedures with large scale data use. This so-called "Automated Valuation Systems" used to be less widespread in Hungary, but there have been encouraging results in this area (Szücs et al., 2016; Vinogradov, 2009). However, at the international level, a methodology was developed as early as the 1970s and examples of its widespread application can also be found (Glumac and Rosiers, 2018; Lóczy, 2002). The use of high-volume valuations for collateral purposes in residential real estate is limited by or subject to conditions of an EU regulation (Directive 2014/17/EU), but land valuation is not restricted. However, automatic valuation may be needed in areas of public administration and portfolio management, in addition to collateral purposes (Bencure et al., 2019). It is also important to mention that the methodology used is also in line with the International and European Valuation Standards (IVS, EVS) (Viitanen, 2005).

The sale and purchase of pastures, meadows and grasslands is significantly smaller compared to the territorial share of the agricultural land use category. Besides this value depends on the given part of the country and varies between counties, i.e. the lack of appropriate comparative data is also a problem when it comes to real market valuation. It is a generally accepted approach among experts that in settlements or districts where a sufficient number of comparative data are not available, the value of the nearby arable land is taken as a basis and it is multiplied by a land use category multiplier of meadow or pasture. This procedure involves evaluation risk, however, supported by appropriate studies, it may be applicable within a given framework for rapid and high-volume evaluations. The fact that the data related to land sales and leases in Hungary must be made public through an announcement (Govt. decree no. 474/2013) ${ }^{2}$ is a key help for professional evaluators who are able to handle large data sets. With the appropriate technical and professional background, these data can be collected continuously, thus creating a comprehensive national database suitable for detailed analysis, which, according to the group comparison principle, allows for determining the value of arable land and the various

\footnotetext{
${ }^{1}$ 1203/2016. (IV. 18.) Government Resolution on the measures necessary to perform the sale of state - owned land to farmers under the program "Land for Farmers!"

${ }^{2}$ On the Announcements page, authorities specified in Act CL of 2016 on the general rules of administrative authority procedure and those connected to the Central Electronic Service System (Central System (KR)) as specified in Act No. 474/2013 (XII. 12.) on sales and lease contracts in the interest of excercising pre-emption and pre-lease rights shall fulfill their publication liability.
}

land use categories for a given topographical lot number or subdivision.

Large scale land valuation can provide an additional opportunity to develop or even implement comprehensive land policy concepts (Dorgai et al., 2004), especially in underdeveloped areas, where land use types (e.g. ploughed pasture, woodland, cut or neglected orchards used as pastures, etc.) other than the one in the public register are also widespread. Land valuation based on an approximate estimate can provide useful and rapid value-based information for monitoring speculative transactions (Bíró, 2007) and facilitate appropriate and timely administrative and legal interventions, as well as an additional source of information on other land use-related management and administrative issues (Fehér et al., 2007), while it may be used in related official or civil matters. In addition, in certain zones suitable for regional development, mass valuation or forecasting of land prices can also increase the effectiveness of environmental measures (EEA, 2010).

The main goal of this research was to create an evaluation procedure based on the data of the areas belonging to the agricultural land use category on the land market, which allows the large scale evaluation of land use types (meadow and pasture) less frequently sold and purchased which are significantly differentiated in size, utilisation and other relevant value-creating factors, within certain confidence limits. As a first step, the relationship between arable land and pasture and meadow prices had to be explored, as well as regional and local specificities. Based on the obtained data, the "land use category multiplier" can be determined at regional, county and even district level, which allows the estimation of potential meadow and pasture prices from the typical agricultural land prices in the given conditions. The performed correlation analyses also make it possible to determine an estimation function.

According to the data of the HCSO (2020), since 2010, about 79\% (7.4 million hectares) of Hungary's 9.3-million-hectare area is crop(farm)land. More specifically, there were nearly 5.3 million hectares of agricultural land and 1.9 million hectares of forest in Hungary in 2019 (June 1), the former occupying 58\% and the latter $21 \%$ of the country's total land area. The $46 \%$ share of arable land (4318000 hectares) slowly decreased over the years. The area under vines $(68$ thousand hectares) has shrunk by $17 \%$ since 2010 . Grassland area involved in farming (790 thousand hectares in 2019) increased by $4 \%$ during the same period.

According to the HCSO (2019), on 1 June 2018, the size of the production area in Hungary was 7 million 356 thousand hectares, covering almost $79 \%$ of the country's territory. A significant part of the production 
area (5.3 million hectares) is agricultural land, divided between arable land, gardens, vineyards, orchards and grasslands. The agricultural area decreased by 8.5 thousand hectares in one year, which can be explained mainly by the withdrawal of abandoned grasslands and vineyards and uncultivated gardens, while there was a slight increase in the orchard land use type (Figure 1).

Figure 1. Land use in Hungary in each land use category (thousand hectare)

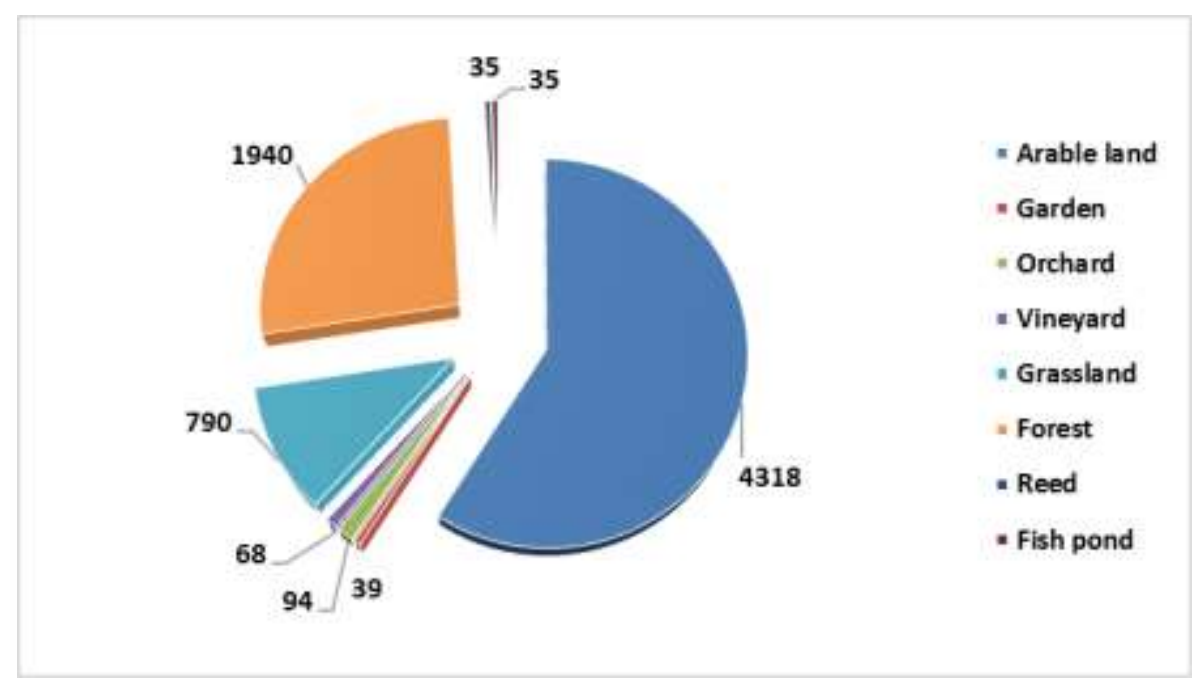

Based on the HCSO analyses, it can be concluded that in 2018, 63\% (3199 thousand hectares) of the agricultural area used for farming purposes was cultivated by individual farms, while 37\% (1918 thousand hectares) was used by companies.

The distinction between the individual land use types is mostly made according to statistical, registration, administrative, legal and settlement organization aspects. Based on the internationally or globally standardized classification, several organizations perform surveys, analyzes, and forecasts covering the entire global economy or specific regions, some of the most important of which are: FAO (Food and Agriculture Organization of the United Nations), SEEA (System of Environmental-Economic Accounting), IPCC (The Intergovernmental Panel on Climate Change) and WCA (World Program for the Census of Agriculture). With some exceptions, the Hungarian statistical classification is basically the same as the terms used by international organizations (minor differences in definitions occur between individual organizations).

The basis of rational land use is that there is an appropriate level and economically interpretable separation between the different types of land use. Regarding agricultural land use, in accordance with the common practice in agricultural management, proportion values are used for each land use type in order to compare their productivity, production potential and utilisation. Considering the fact that in Hungary, the proportion of arable land is dominant in land use, arable land was considered a basic unit (in professional parlance, it is called arable land unit, or reduced arable land) and the value of other land use types was determined in comparison to this unit (Table
1). In the practice of the farm and enterprise economics of the 1960s and 1970s, the following arable units were applied to each land use type, initially specified for a cadastral area unit and later for a hectare (Gönczi et al,, 1967; Csete et al., 1974).

Consequently, the arable land unit expresses the land use referring to the intensity, which makes it possible to differentiate the individual land use types according to the intensity of use. However, the dangers inherent in this method of comparison must also be taken into account, as different methods of cultivation, local soil and climatic conditions, and the technologies used may override these values.

Table 1. Arable land unit value of each land use type

\begin{tabular}{lc}
\hline \multicolumn{1}{c}{ Land use type } & Arable land unit \\
\hline 1 ha arable land & 1 \\
1 ha irrigated arable land & 1.6 \\
1 ha meadow & 0.5 \\
1 ha pasture & 0.2 \\
1 ha orchard & 4.0 \\
1 ha vineyard or hop-yard & 5.0 \\
1 ha nursery garden & 8.0 \\
1 ha fish pond & 0.01 \\
\hline
\end{tabular}

Source: Csete et al., 1974.

Land demand is affected by a number of factors, which sometimes have opposite directions. The effect of each factor can hardly be quantified accurately. Lifting restrictions on the sale and purchase of lands, tightening land use obligations, reducing taxes and 
levies on land transactions, rising land prices, the income-generating ability of agricultural production, the opening agricultural price scissors, certain incentive programs / schemes for land supply, declining and aging agricultural population, changing land lease fees, changes in the rural employment situation, inflation and the increase in farm size can all have an impact on supply trends. Today, the value of land tends to be determined by the economic environment significantly more than the income-generating capacity of land itself on the market (Szücs et al., 2013).

In Hungary, the market value of land is still mostly based on the old "gold crown" (AK) value, although there have been many changes in the nearly one hundred and fifty years since its introduction. Today, the value of land is largely determined by its location, productive value, and the transparency of ownership. Currently, land, including arable land, is determined mostly on the basis of sale and purchase data. In practice, the method based on yield calculation, which focuses on the productivity of land, only partially affects its value, especially because of the constantly increasing value in relation to the investor capital appearing in the system. The value of arable land is constantly rising, i.e. strong demand positions are emerging in the land market. In addition, not only those involved in agriculture buy land, but also financial investors. Consequently, anything that serves production security has a price-increasing effect for both producers and investors (Hollósi et al., 2018).

In arable crop production, increasing farm size is clearly the most important driver of the land market. In 2017 and 2018, arable land prices increased the most in the land market. This phenomenon is related not only to the state land program, but also to the fact that the vast majority of land supply is represented by arable land and the market is characterised by strong demand. Since no two lands or sales situations are the same, each land transaction is unique and the value of each land is different. Income-generating capacity, which is closely linked to productivity, should have the greatest impact on land prices, however, the available subsidisation is one of the most important factors today, which is subject to the area's land use type, the crop produced on the field and eligibility for subsidisation in general. The demand for fertile land, especially for arable land, typically grows faster than supply (Fórián, 2018).

However, the new Land Traffic Act came into force in 2014 and it drastically rearranged the land market. The potential range of land buyers has significantly decreased. In the past, almost all Hungarian citizens could exercise their right to acquire property. Based on the new regulation, it was not the people who cultivated land, but only official farmers, i.e. less than two hundred thousand people could acquire land ownership. Meanwhile, the number of landowners remains around 1.5-2 million people, mostly with very small plots. However, the reduction in demand has not yet materialized in the short term for various reasons. On the one hand, the income position of commodityproducing individual farmers has significantly improved due to the favourable subsidisation and market environment, and they wanted to invest the resulting additional resources in the land market. On the other hand, the 2008 crisis and the subsequent declining outputs drastically increased the value of arable land as an investment. An evidence for this phenomenon is that many investors took a course to officially become a farmer in order to buy land. The biggest boost came from the "Land for Farmers" program, i.e. the sale of state-owned land, including the sale of plots of land exceeding 3 hectares by auction. The starting prices in many areas far exceeded the usual market prices established locally, which resulted in a general price increase (Máhr, 2018).

In Hungary, the land market and the land lease market are separated from each other, they operate separately and convey different, sometimes opposite effects and information to producers and owners. The value of land is a theoretical category and the price of land intended to display this value is not always reasonably related to the value of arable land, but it may even differ permanently. Agricultural policy and, more specifically, land tenure policy, as well as inherited farming conditions influence land use and, consequently, land value and land prices (Kapronczai, 2018).

According to the data of the HCSO (2018), the volume of land sales in 2017 decreased to the level of two years earlier, partly due to the fact that the program called "Land for Farmers" ended, as it resulted in extraordinary land sales in 2016. The area of agricultural and forestry land sold was 73 thousand hectares, almost a third of the 2016 sales. The increase in the price of arable land continued to a lesser extent, however (Figure 2), prices in 2017 were on average $5.6 \%$ higher than in 2016 . The average price of arable land, i.e. the most important land use category, was 1350600 HUF per ha. The increase in land lease fees also slowed down: in 2017, the average annual lease of one hectare of arable land was 52300 HUF, 5.8\% higher than in 2016.

The average price of arable land per hectare was the highest in the Southern Great Plain (1.5 million $\mathrm{HUF} / \mathrm{ha}$ and remained above 1.2 million HUF in all regions except Northern Hungary (925000 HUF/ha). In addition, there are significant price differences depending on land quality and other factors not only between regions, but also within regions. In the same region, the price per hectare of good quality land may even be twice as that of a poor quality land (HCSO, 2018). It is important to note that land prices deviated much more from the average, e.g. on the Hajdúság loess ridge near Debrecen, where the price of arable land with a gold crown value of about 40-45 AK/ha reached even up to 4.5-5.0 million HUF/ha in several cases.

According to the data of the HCSO, the average price of arable land was the highest in Hajdú-Bihar, Tolna and Békés counties in 2017 (1.7-1.8 million $\mathrm{HUF} / \mathrm{ha}$ ), and the lowest in Zala, Borsod-AbaújZemplén and Nógrád counties (700-900 thousand HUF/ha). 
Figure 2. Average arable land prices in each land use type in Hungary

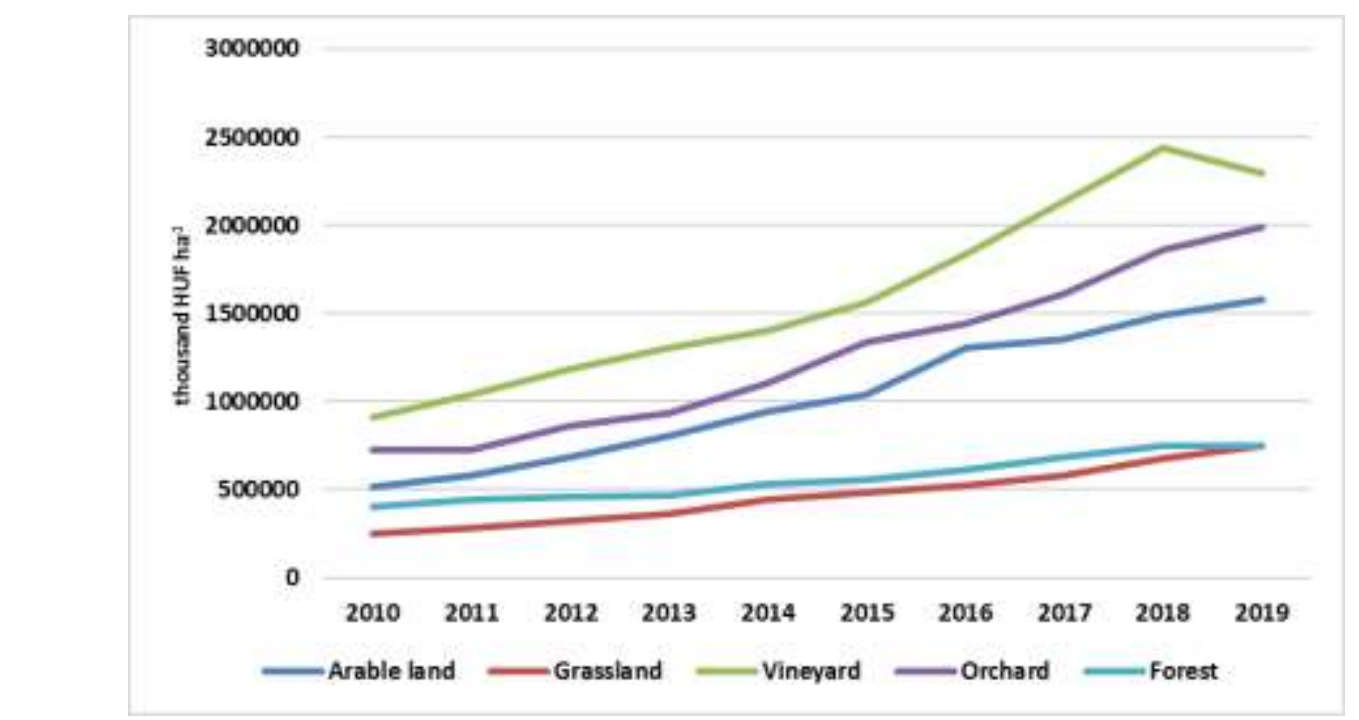

Source: HCSO, 2019.

\section{MATERIALS AND METHODS}

The applied methodological procedure takes the dominant arable land prices in the Hungarian agricultural production as a basic unit of valuation and compares the pasture and meadow prices to this value. The methodology used in this study is in accordance with the methodological guidelines of the European Union related to land prices and lease fees (DG AGRI, 2017). The data used for the study were obtained from the Starterra database of the asset valuation company Biblio-Markt Ltd. More specifically, the data of 2018 and the first quarter of 2019 were in focus. The database was processed in order to extract transaction data related to arable land, meadows and pastures from the national data set. Due to the fact that the processing of the entire database would have required a very long time and technical input, the analyses were performed on the basis of sample area data (counties and districts). When selecting district data for a given county, the availability of most arable land, meadow and pasture data was crucial.

The Biblio-Terra database contains the complete reported data set provided by the authorities specified in Act CL of 2016 on the Code of General Administrative Procedure and the offices connected to the Central Electronic Service System (Central System - KR) fulfilling their publication liability in accordance with Act No. 474/2013 (XII. 12.) on sales and lease contracts in the interest of exercising pre-emption and pre-lease rights based on sale and purchase and lease agreements. The database contains information on published land sales and lease fees.

The database complies with the requirements set out in the 2003 publication of EVS (European Valuation Standards) (MAISZ, 2003) and the requirements detailed in its annual editions, especially the aspects laid down in the S4, S5 and S6 standards and the GN7,
GN9 guidelines. Furthermore, the data published in the database can be used for both market- and annuitybased valuation in accordance with the Ministry of Agriculture Decree no. 54/1997 (VIII.1.) on the methodological principles of determining the collateral value of farmland.

Of the nearly 30000 transaction data, the sales and purchase data of about 7100 arable land areas, nearly 200 meadows and close to 600 pastures were processed and analysed on a county basis, followed by the determination of the multipliers of Hungarian meadows and land use types by using area-weighted means (Table 2). During the processing of data, speculative transactions and possible data errors in the published database were filtered out based on expert analyses. Examined land use types registered in the Starterra database were the followings: arable land, pasture, grassland/meadow, forested area, orchard, vineyard, fish pond, reed, garden, swamp, road, enclosed garden.

When determining the value of the different subparts of the various land use types (LUT), we used the "LUT" multiplication method, expressing the difference in market value resulting from different utilisation. This method takes the value of the arable land as a basic unit and compares it with the value of each land use type. For this reason, when using the "LUT" multiplier, the price of arable land is a reference basis. The value of the "LUT" multiplier ranges from 0.1 to 1.0 for each land use type. The "LUT" multiplier shall not be applied in the case of forest, vineyard and orchard land use types and for properties classified as "enclosed garden", regardless of their scale. Furthermore, the "LUT" multiplier shall not be applied if the property is in a natural state other than its land use type. The "LUT" multiplier values were determined on the basis of the calculations performed from the sample area data extracted from the Starterra database for each county and part of the country. 
Table 2. Key features of the data included in the study

\begin{tabular}{lccc}
\hline \multicolumn{1}{c}{ Description } & Arable land & Meadow & Pasture \\
\hline ALL DATA (country-wide) (no.) & 27051 & 1467 & 2171 \\
BASIC SET (district sample areas) (no.) & 4159 & 225 & 365 \\
Representativity (All data/Basic set) (\%) & 15 & 15 & 17 \\
\hline
\end{tabular}

Source: Biblio-Markt Ltd. - Starterra database

Calculations were performed with Excel, and statistical analyses were done with the Analysis ToolPAck extension. Empirically obtained results were subjected to further statistical analysis using " $R$ ".

\section{RESULTS AND DISCUSSION}

In Hungary, the National Land Fund, established in 2001 (its successor is called the National Land Centre) as the largest land asset management organization, introduced a separate valuation method in 2002 for the simplified and rapid valuation of arable land under its management. The value was determined on the basis of annuity, which can be used to obtain the value of arable land by calculation. The value of the given area can be determined by using a correction factor for each land use type other than arable land. This method also had shortcomings, but it allowed for its original purpose, i.e. rapid, low-cost, approximate valuation. In accordance with the land use types set out in the Govt. Decree no. 254/2002. (XII 13.), the following multipliers were used: arable land: 1.0; meadow: 0.8; pasture: 0.4 , garden: 1.0 .

Conversion to an equivalent value for property valuation purposes has no references in international literature. In agronomic practice, however, the Land Equivalent Ratio (LER) used to compare land use types is internationally widespread. The methodology for calculating the land equivalent ratio is very different, but the principle of calculation is mostly based on a statistical procedure (Oyejola and Mead, 1981). In addition, the comparison of individual land use types may also be performed for environmental protection, emission and load (Havranek et al., 2007) or food safety purposes (Yongzhong et al., 2018). Based on this method, the authors of this paper consider it possible to perform a derived asset valuation possible through appropriate economic conversion.

There are very significant differences in the price of arable land and pasture in the countries of the European Union, depending on the type of use in production (EC, 2018). For example, in some countries, land prices of grazing dairy farms may even exceed that of arable land (Silvis and Voskuilen, 2018). Income from land use has a decisive role in land prices (Szücs, 1998). However, land prices may be significantly affected by institutional factors only indirectly or not at all related to production, such as taxes related to land and other economic activity, direct and indirect subsidies, reimbursements to maintain the ecosystem, inflation, as well as land demand for urban and infrastructural purposes (European Environment Agency, 2010). In addition, Swinnen et al. (2008) consider crop and input prices as indirect factors affecting land prices.

Eurostat provides regular data on land prices and lease fees in the Member States, but there is no uniform long time series data. However, the data for some countries are incomplete in several cases. In the western European Member States, the available data show that the difference in value between arable land and pasture is lower than in the East or the Central Region. In the period between 1997-2009, according to Eurostat, the average pasture price in Belgium reached $85 \%$ of the arable land price, while the same value was $73 \%$ in France and $99 \%$ in the Netherlands. According to the 2005-2009 data, pasture prices in Poland accounted for $67 \%$ of arable land (Eurostat, 2001; 2019). In recent years, the difference between the lowest (pasture) and highest (mainly arable) land prices in Britain was higher than 60\%. (Naárné and Varga, 2017). According to surveys performed in the Visegrád countries, the difference between the lowest and highest farmland prices exceeded $100 \%$ (Söreg et al., 2017).

The total transaction value of the arable lands included in the study exceeded 10 billion HUF, which included nearly 7,000 hectares. The valuee of the transaction was around 180 million HUF in the case of meadows and 320 million HUF in the case of pastures. As regards sale and purchase, the data of 4,159 arable lands, 25 meadows and 365 pastures were used.

Based on the data in the table, the multiplier of $\mathbf{0 . 6 4}$ was accepted as the national average for the meadow land use type and $\mathbf{0 . 3 9}$ for the pasture land use type. The obtained values are significantly lower in comparison with the land use type multipliers laid down in the Govt. Decree no. 254/2002. The aggregate results of the calculation broken down to country parts are shown in Table 3, while county-based values are shown in Table 5 .

In terms of relative and absolute differences, significant differences can be observed in each region. The meadow value closest to the arable land is found in Northern Hungary, followed by the values of the Central and Southern Transdanubia regions. The price of areas classified as pasture in Central Transdanubia and Northern Hungary is barely half the value of arable land. In relative comparison, the value of pastures in Western and Central Transdanubia was close to that of the meadow land use type $(68 \%$ and $69 \%$, respectively), while the largest difference can be found in the South and North Great Plain regions. The largest difference between meadow and pasture prices was observed in the North Great Plain (0.31). 
Table 3. Results of the analysis

\begin{tabular}{|c|c|c|c|c|c|}
\hline \multicolumn{3}{|c|}{ Arable land } & \multirow{2}{*}{\multicolumn{3}{|c|}{ Obtained values }} \\
\hline $\begin{array}{l}\text { Arable land - sample } \\
\text { area (ha) }\end{array}$ & $\begin{array}{l}\text { Value of transaction } \\
\text { (thousand HUF) }\end{array}$ & $\begin{array}{l}\text { Unit price - arable land } \\
\text { (thousand HUF/ha) }\end{array}$ & & & \\
\hline 7111 & 10192292 & 1433 & & & \\
\hline \multicolumn{3}{|c|}{ Meadow } & \multicolumn{3}{|c|}{ Meadow multiplier } \\
\hline $\begin{array}{l}\text { Meadow - sample } \\
\text { area (ha) }\end{array}$ & $\begin{array}{l}\text { Value of transaction } \\
\text { (thousand HUF }\end{array}$ & $\begin{array}{l}\text { Unit price - meadow } \\
\text { (thousand HUF/ha) }\end{array}$ & $\begin{array}{l}\text { calculated } \\
\text { multiplier }\end{array}$ & Min. & Max. \\
\hline 196 & 180310 & 922 & 0.64 & 0.57 & 0.94 \\
\hline \multicolumn{3}{|c|}{ Pasture } & \multicolumn{3}{|c|}{ Pasture multiplier } \\
\hline $\begin{array}{l}\text { Pasture - sample area } \\
\text { (ha) }\end{array}$ & $\begin{array}{l}\text { Value of transaction } \\
\text { (thousand HUF }\end{array}$ & $\begin{array}{l}\text { Unit price - pasture } \\
\text { (thousand HUF/ha) }\end{array}$ & $\begin{array}{l}\text { Calculated } \\
\text { multiplier }\end{array}$ & Min. & Max. \\
\hline 581 & 321347 & 554 & 0.39 & 0.31 & 0.62 \\
\hline
\end{tabular}

Source: Own calculations based on the Biblio-Starterra database

Table 4. Differences between land use type multipliers in Hungarian regions

\begin{tabular}{lccccc}
\hline & Arable land & Meadow & Pasture & M/P & M-P \\
\hline Central Hungary & 1 & 0.63 & 0.42 & $66 \%$ & $\mathbf{0 . 2 1}$ \\
Western Transdanubia & 1 & 0.65 & 0.45 & $68 \%$ & $\mathbf{0 . 2 1}$ \\
Central Transdanubia & 1 & 0.73 & 0.51 & $69 \%$ & 0.23 \\
Southern Transdanubia & 1 & 0.73 & 0.48 & $66 \%$ & 0.24 \\
North Hungary & 1 & 0.83 & 0.54 & $65 \%$ & 0.29 \\
North Great Plain & 1 & 0.68 & 0.36 & $54 \%$ & $\mathbf{0 . 3 1}$ \\
South Great Plain & 1 & 0.64 & 0.37 & $57 \%$ & 0.27 \\
National average (weighed) & 1 & $\mathbf{0 . 6 4}$ & $\mathbf{0 . 3 9}$ & $60 \%$ & 0.26 \\
\hline
\end{tabular}

Source: Own calculations based on the Biblio-Starterra database

However, there are limitations to the applicability of this procedure. An estimate was made of the potential meadow and pasture prices using the arable land prices and compared them with the real transaction data. Based on the obtained results, significant overestimation was found in meadow and pasture prices above initial arable land prices of 2 million HUF.
However, determining the extent of possible corrections requires a separate analysis. In order to further examine the practical applicability of the assessment, a correlation analysis was performed at the data level of arable land, meadow and pasture data of the county- and district-based sample means (Figure 3).

Figure 3. Results of the correlation analysis of arable land and meadow prices

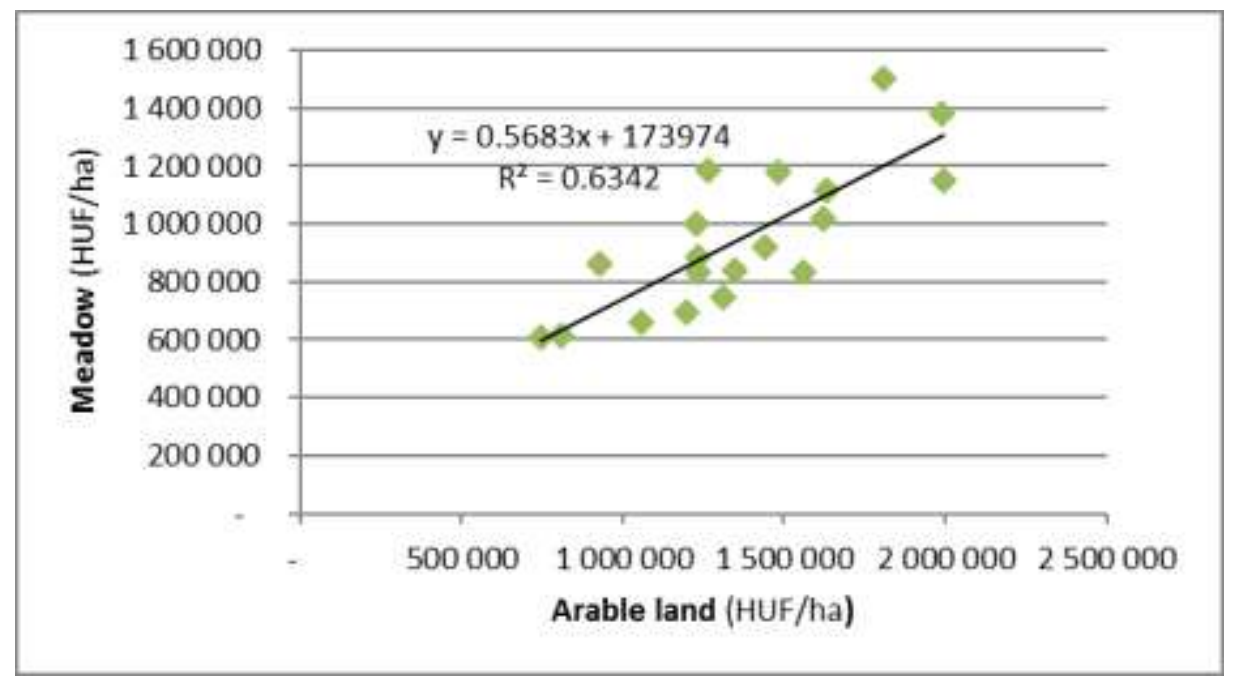

Source: Own calculations based on the Biblio-Starterra database 
Based on the database of arable land and meadow prices, there is a linear relationship between the prices of these two land use types, as the Pearson's correlation coefficient (0.796) indicates a strong linear correlation. The obtained value is strongly significant. According to the performed regression analysis, based on the known arable land prices, meadow prices can be estimated with an average accuracy of 157,000 HUF. The linear estimation function is as follows:

$$
\text { Meadow prices }(\mathrm{HUF})=0.5683 \mathrm{x} \text { arable land prices }(\mathrm{HUF})+174000 \mathrm{HUF}
$$

Knowing the arable land prices, the changes in meadow prices can be explained to an extent of $63.42 \%$ using the above correlation.
(The results of further goodness of fit tests showed that the highest $R 2$ value for meadow is shown by the exponential trend function (0.657), the estimation function of which is as follows: $y=404699 e 6 E-07 x$ )

Figure 4. Results of the correlation analysis of arable land and pasture prices

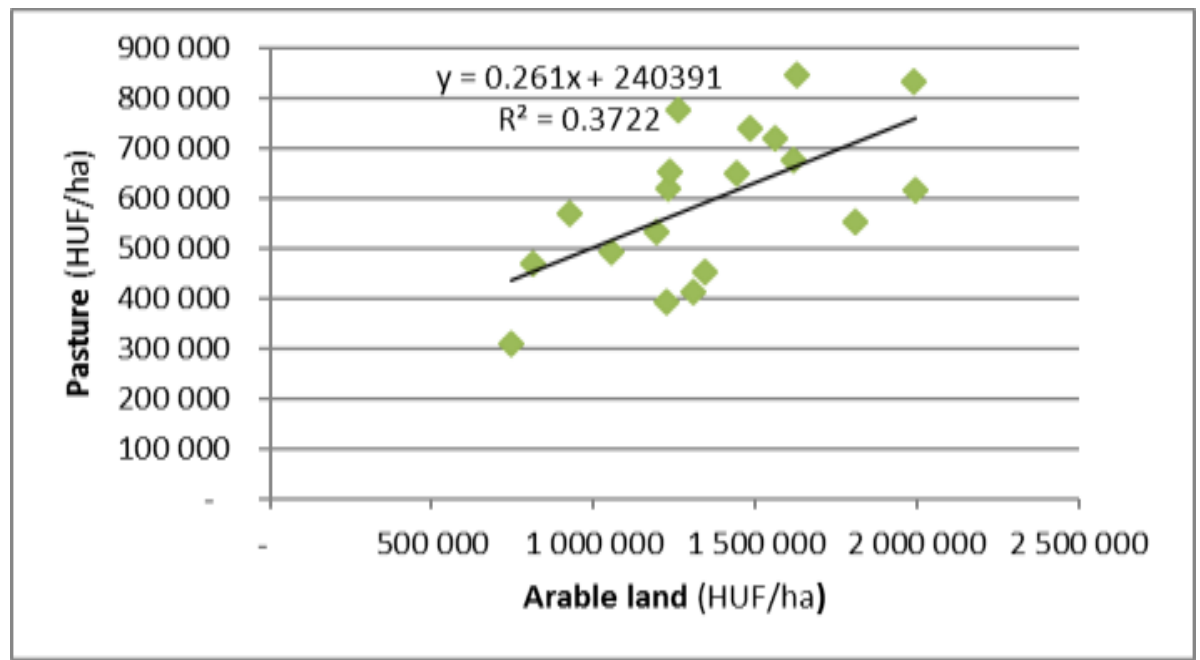

Source: Own calculations based on the Biblio-Starterra database

With regard to arable land and pasture prices, there is a moderately strong linear relationship between the two categories. The value of Pearson's product moment correlation coefficient is 0.61 . This value is also strongly significant (Figure 4).

\section{Pasture prices $(\mathrm{HUF})=0.261 \mathrm{x}$ Arable land prices $(\mathrm{HUF}) 240400 \mathrm{HUF}$}

Based on arable land prices, meadow prices can be estimated relatively more accurately than pastures, due to the lower standard deviation of the latter. The accuracy of estimation may be slightly misleading, as meadow prices are nearly twice as high as pasture prices. The standard deviation of meadow prices is much higher, as the magnitude of relative standard deviation can be clearly seen in the Figure 4 . This is the reason why changes in arable land prices explain only $37 \%$ of the changes in pasture prices.

(The results of further goodness of fit tests showed that the highest $R 2$ value for pasture resulted from the power function (0.4128), the estimation function of which is $y=69.687 \times 0.6402)$.

\section{CONCLUSIONS}

In the opinion of the authors, the land price estimation based on the results of this study can be used not only for price and value determination in
Based on the known arable land prices, the pasture prices can be estimated with an average accuracy of $123300 \mathrm{HUF}$. The linear estimation function is as follows:

administrative, lending and asset management matters, but also in transactions that must comply with the European Commission's official and state land sales regulations (see EC 97/C 209/03, 1997).

The differences between the value determination based on the large scale land valuation method and the individual evaluations carried out on a random basis for control purposes were negligible, allowing the procedure to be applied in practice under certain conditions. However, above a certain threshold (arable land prices of about 2 million HUF), this method is of limited application as it results in significant overestimation, the remedy of which requires further analyses.

The obtained results show that, under certain conditions, arable land prices can provide a suitable starting point for the large-scale evaluation of meadow and pasture land use types. According to the performed analyses, the land use type multipliers in Annex 1. of the Govt. Decree no. 254/2002 (XII. 13.) are less 
suitable for determining realistic market value, mainly due to the fact that county level data show rather significant variance. County or regional data are much more representative of regional characteristics. In addition, a possible correction of $+-10 \%$ to be used by experts carrying out individual assessments is considered acceptable, on the basis of expert judgment.

However, it should be taken into account that this procedure was developed empirically, based on professional and practical considerations, as opposed to the AVM-based procedures based on in-depth statistical and econometric models, mainly applied in other countries. At the same time, based on the performed tests and the obtained results, it can be concluded that, in terms of practical applicability, this procedure can provide significant support to the value tracking of major arable land portfolios, as well as forecasting, and it provides opportunities for the asset valuation of large areas or zones, it serves useful information in collateral valuations and guidance in the process of preparing certain agricultural policy decisions of administrative nature.

Table 5. Land use type multipliers by counties

\begin{tabular}{|c|c|c|c|c|c|c|c|c|c|c|}
\hline \multicolumn{11}{|c|}{ DETAILED ANALYSIS RESULTS } \\
\hline & \multirow[b]{2}{*}{ Sample zone } & \multicolumn{3}{|c|}{ Arable land } & \multicolumn{3}{|c|}{ Meadow } & \multicolumn{3}{|c|}{ Pasture } \\
\hline & & $\begin{array}{c}\text { LUT } \\
\mathbf{x}\end{array}$ & ha & $\begin{array}{c}\text { Average } \\
\text { price }\end{array}$ & LUT $x$ & ha & $\begin{array}{c}\text { Average } \\
\text { price }\end{array}$ & $\begin{array}{c}\text { LUT } \\
\mathbf{x}\end{array}$ & ha & $\begin{array}{c}\text { Average } \\
\text { price }\end{array}$ \\
\hline Pest county & Cegléd & 1 & 589 & 1621579 & 0.63 & 34.74 & 1016779 & 0.42 & 34.91 & 675549 \\
\hline $\begin{array}{l}\text { Györ-Moson- } \\
\text { Sopron co. }\end{array}$ & Sopron-Fertőd & 1 & 439.5 & 1989473 & 0.69 & 13.47 & 1380377 & 0.42 & 2.64 & 834535 \\
\hline Vas county & Körmend & 1 & 268.5 & 1441327 & 0.64 & 5.19 & 919191 & 0.45 & 2.46 & 648989 \\
\hline Zala county & Zalaegerszeg & 1 & 277.1 & 1055802 & 0.63 & 30.19 & 663175 & 0.47 & 6.21 & 492439 \\
\hline Fejér county & Martonvásár & 1 & 369.5 & 1630969 & 0.69 & 7.21 & 1118426 & 0.52 & 2.93 & 846097 \\
\hline $\begin{array}{l}\text { Komárom- } \\
\text { Esztergom co. }\end{array}$ & Kisbér & 1 & 158.2 & 1483460 & 0.79 & 3.30 & 1178425 & 0.50 & 13.44 & 741551 \\
\hline Veszprém county & Pápa & 1 & 489.5 & 1233396 & 0.72 & 11.98 & 884904 & 0.50 & 28.32 & 620651 \\
\hline Baranya county & Pécsvárad & 1 & 77.79 & 1263101 & 0.94 & 9.54 & 1183576 & 0.62 & 7.94 & 776861 \\
\hline Somogy county & Marcali & 1 & 212.4 & 1235630 & 0.67 & 16.15 & 831409 & 0.53 & 28.86 & 651909 \\
\hline Tolna county & Tamási & 1 & 428.9 & 1997031 & 0.58 & 4.41 & 1148754 & 0.31 & 30.72 & 617889 \\
\hline $\begin{array}{l}\text { Borsod-Abaúj- } \\
\text { Zemplén co. }\end{array}$ & Edelény & 1 & 135.4 & 748306 & 0.81 & 16.72 & 607311 & 0.41 & 46.39 & 309782 \\
\hline Heves county & Eger & 1 & 221.8 & 928401 & 0.93 & 1.49 & 860427 & 0.61 & 25.33 & 570859 \\
\hline Nógrád county & Balassagyarmat & 1 & 479.2 & 811139 & 0.76 & 12.64 & 612972 & 0.58 & 53.79 & 471311 \\
\hline Hajú-Bihar county & Berettyóújfalu & 1 & 704.1 & 1808615 & 0.83 & 10.19 & 1502228 & 0.31 & 84.85 & 553219 \\
\hline $\begin{array}{l}\text { Jász-Nagykun- } \\
\text { Szolnok co. }\end{array}$ & Jászberény & 1 & 916.6 & 1347532 & 0.62 & 3.30 & 836605 & 0.34 & 36.85 & 454260 \\
\hline $\begin{array}{l}\text { Szabolcs-Szatmár- } \\
\text { Bereg co. }\end{array}$ & Vásárosnamény & 1 & 197 & 1194795 & 0.58 & 4.31 & 695267 & 0.45 & 17.21 & 533024 \\
\hline $\begin{array}{l}\text { Bács-Kiskun } \\
\text { county }\end{array}$ & Kecskemét & 1 & 481.8 & 1562175 & 0.53 & 7.19 & 833490 & 0.46 & 82.13 & 721533 \\
\hline Békés county & Szeghalom & 1 & 469.6 & 1228509 & 0.81 & 1.67 & 1000000 & 0.32 & 28.24 & 393661 \\
\hline Csongrád county & Hódmezővásárhely & 1 & 194.5 & 1310034 & 0.57 & 1.83 & 745042 & 0.31 & 47.34 & 412040 \\
\hline $\begin{array}{l}\text { National average } \\
\text { (weighted) }\end{array}$ & & . & & 1433351 & 0.64 & & 922267 & 0.39 & & 553507 \\
\hline Sample area (ha): & & & 7111 & & & 196 & & & 581 & \\
\hline
\end{tabular}

Source: Own calculations based on Biblio-Starterra.database

*Land use type (LUT)

\section{REFERENCES}

Apáti, F.-Berde, Cs.-Blaskó, B.-Felföldi, J.-Madai, H.-Nábrádi A.Pupos, T.-Szénásné Ványi, N.-Szőllősi, L.-Szücs, I. (2013): Vállalati és ágazati gazdaságtani ismeretek, Debreceni Egyetem Gazdálkodástudományok Centruma, Debrecen, p. 1-292. ISBN 978-615-5183-52-2, (Szerk. Apáti, F.)

Bencure, J.C.-Tripathi, N.-Miyazaki, H.-Ninsawar, S.-Minsusn, S.K. (2019): Development of an Innovative Land Valuation Model (iLVM) for Mass Appraisal Application in Sub-Urban Areas Using AHP: An Integration of Theoretical and Practical
Approaches. Sustainability 2019, 11, 3731. MDPI, Basel, Switzerland. p. 56.

Biró, Sz. (2007): Külföldi földtulajdonszerzés lehetőségének értékelése. - Földminősítés, földértékelés és földhasználati információ a környezetbarát gazdálkodás versenyképességének javításáért. Keszthely, 2007. november 22-23. - BudapestKeszthely: MTA Talajtani és Agrokémiai Kutatóintézet. p. 287294. 
Biró, Sz.-Popp, J.-Kapronczai, I.-Máhr, A.-Tresó, I.-Hollósi, D.Fórián, Z. (2018): Milyen tényezők határozzák meg a termőföld értékét a szántóföldi művelésben? Budapest: Agronapló, URL: https://www.agronaplo.hu/szakfolyoirat/2018/04/gazdasag/mily en-tenyezok-hatarozzak-meg-a-termofold-erteket-a-szantofoldimuvelesben

Csete, L.-Gönczi, I.-Kádár, B.-Vadász, L. (1974): Mezőgazdasági vállalatok és üzemek gazdaságtana. Közgazdasági és Jogi Könyvkiadó, Budapest.

Csete, L.-Gönczi, I.-Kádár, B.-Vadász, L. (1974): Mezőgazdasági vállalatok és üzemek gazdaságtana. Közgazdasági és Jogi Könyvkiadó, Budapest.

DG AGRI - Directorate-General of the European Commission for Agriculture and Rural Development (2017): Common Methodology on Land Prices and Rents. Working Group on Agricultural Accounts and Prices, 1-2 December 2010 (Annex 1 of document ASA/AAP/133). Luxembourg.

Dorgai, L. szerk. (2004): A Magyarországi birtokstruktúra, birtokrendezési stratégia megalapozása. Agrárgazdasági Tanulmányok. 6. sz. Agrárgazdasági Kutató Intézet. Budapest.

EEA (European Environment Agency) (2010): Land in Europe: prices, taxes and use patterns. Technical report. No.4. Copenhagen. pp. 14-16.

El-Barmelgy, M.M.-Ahmad, M.S.-Usama, A.N.-Shaimaa, M.A. (2014): Economic Land Use Theory and Land Value in Value Model. International Journal of Economics and Statistics. Volume 2. Centre for Environment \& Socio-Economic Research Publication. Roorke. p. 45.

Európai Parlament és Tanács (2014): 2014/17/EU irányelv. A lakóingatlanokhoz kapcsolódó fogyasztói hitelmegállapodásokról, valamint a 2008/48/EK és a 2013/36/EU irányelv és az 1093/2010/EU rendelet módosításáról. p. 8.

European Comission (1997): Commission Communication on State aid elements in sales of land and buildings by public authorities. Official Journal of the European Communities - C 209/3. Brussels. pp. 3-6.

European Comission (2018): Land cover and land use. DG Agriculture and Rural Development, Unit Farm Economics. (https://ec.europa.eu/agriculture/sites/agriculture/files/statistics/ facts-figures/land-cover-use.pdf)

European Environment Agency (2010): Land in Europe: prices, taxes and use patterns. Techical report. 4/2010. Office for Official Publications of the European Union. Luxembourg.

Eurostat (2019). Agricultural land prices by region. https://ec.europa.eu/eurostat/web/productsdatasets/product?code=apri_lprc

Fehér, I.-Kapuszta, Á.-Vinogradov, Sz.. (2007): A földpiac változásai Magyarországon az EU-csatlakozás után. Földminősítés, földértékelés és földhasználati információ a környezetbarát gazdálkodás versenyképességének javításáért. Keszthely, 2007. november 22-23. - Budapest-Keszthely: MTA Talajtani és Agrokémiai Kutatóintézet. pp. 225-231.

Glumac, B.-Rosiers, F. (2018): Real estate and land property automated valuation systems: A taxonomy and conceptual model. Luxembourg Institute of Socio-Economic Research. Working Papers 2018-09. p. 54.

Gönczi, I.-Kádár, B.-Vadász, L. (1962): Mezőgazdasági vállalatok és üzemek gazdaságtana. Közgazdasági és Jogi Könyvkiadó, Budapest
Havránek, F.-Pavliš, J.-Hučko, B.-Czudek, R. (2007): Alternative Utilisation of Agricultural Land. FAO Publications. Scientific Monographeditet by Rembrandt s.r.o. (http://www.fao.org/3/aai544e.pdf)

HCSO (2019): Statisztikai tükör: Mezőgazdasági termőföldárak és bérleti díjak (2019), Budapest: Központi Statisztikai Hivatal. URL: https://www.ksh.hu/docs/hun/xstadat/xstadat_eves/__omf003.html

Lóczy, D. (2002): Tájértékelés, földértékelés. Dialóg -Campus Kiadó. Budapest-Pécs. p. 206.

MAISZ (Magyar Ingatlanszövetség) (2003): European Valuation Standards. Magyar Ingatlanszövetség - Füti Omega Kft.. Budapest.

Naárné, T.Zs. (2006): A termőföld közgazdasági értéke és piaci ára. Agroinform Kiadó. Budapest p. 1-180.

Naárné, T.Zs.-Varga, J. (2017): Az Angliai és a Magyarországi földminősítési módozatok és földárak összehasonlító elemzése. Studia Mundi - Economica. Vol 4. Nr.3. Szent István Egyetem, Gazdaság- és Társadalomtudományi Kar. Gödöllő. pp. 68-70.

Oyejola, B.A.-Mead, R. (1981): Statistical Assesment of Different Ways of Calculating Land Equivalent Ratios (LER). Axpl. Agric. (1982), vol.8. https://www.cambridge.org/core/services/aop-cambridgecore/content/view/S0014479700013600)

Palen, R. (2018): Land prices vary considerably between and within Member States. Agricultural land prices and rents. Eurostat Press Office 48/2018. p. 75-77.

Silvis, H.-Voskuilen, M. (2018): Agricultural land prices in the EU in 2016. Wageningen Economic Research. Den Haag. 2018-053.

Sőreg Á.P.- Naár A.T.-Naárné T.Zs. (2017): Regionális különbségek és árkonvergencia a visegrádi országok termőföldpiacán. Statisztikai Szemle. 95. évf. 4. sz. pp. 349-381.

Swinnen, J.-Ciaian, P.-Kancs A. (2008): Study on the Functioning of Land Markets in the EU Member States under the Influence of Measures Applied under the Common Agricultural Policy Final Report. Centre for European Policy Studies (CEPS) Brussels.

Szűcs, I. (1998): A föld ára és bére. Budapest: Agroinform Kiadó, p. 160.

Szücs, I.-Farkasné, F.-Vinogradov, Sz. (2016): Kísérlet egy automatizált komplex földértékelési rendszer kidolgozására. Gazdálkodás. 60. Évf. 6 sz. pp. 496-505.

Viitanen, K. (2005): International Valuation Standards and Land Administration. Valuation and Real Estate Management II. From Pharaohs to Geoinformatics FIG Working Week 2005 and GSDI-8 Cairo. p. 74-76.

Vinogradov, Sz. (2009): Szántóföldek komplex közgazdasági értékelése Magyarországon. PhD. disszertáció. Szent István Egyetem - Gazdálkodás- és Szervezéstudományok Doktori Iskola. Gödöllő. pp. 1-151.

Vinogradov, Sz. (2010): Szántóföldek komplex közgazdasági értékelése Magyarországon. Doktori értekezés. Szent István Egyetem. Gazdálkodás és Szervezéstudományok Doktori Iskola. p. 151.

Yongzhong, T.-Ju, H.-Zhenning, Y.-Yonghua, T. (2018): Can Arable Land Alone Ensure Food Security? The Concept of Arable Land Equivalent Unit and Its Implications in Zhoushan City, China. Sustainability 2018, 10, 1024 (www.mdpi.com/journal/sustainability) 